\title{
More Liggett documents, Canadian tips and facts, more from Australia, Formula One critique, Polish dining, plus follow-ups and spoofs
}

Web Watch follows issues relevant to tobacco control on the world wide web. The emphasis is on new sites or new features appearing on the web including relevant URLs and short descriptions of the material. $A$ web site is available featuring the URL links referenced in this column as well as those referenced in past columns; the URL for that site is: <http://www.gate.net/ jcannon/webwatch/>.

\section{More than 800 additional Liggett documents}

On 4 December 1997, the Commerce Committee of the House of Representatives in the United States subpoenaed more than 800 tobacco industry documents in the matter of State of Minnesota et al vs Philip Morris Inc. et al, No C1-94-8563.

Stating that the documents revealed "a conspiracy of silence and suppression of scientific research,” Ramsey County (Minnesota) District Judge Kenneth Fitzpatrick, on 16 December 1997, upheld the conclusions of Special Master Mark W Gehan that 864 previously secret tobacco company documents contained evidence of crime or fraud and therefore were not protected by attorney-client privilege as asserted by tobacco industry lawyers. Judge Fitzpatrick's order is available at:

<http://www.ag.state.mn.us/consumer/tobacco/ Order121797. html>

The 864 documents were among a larger set of papers the Liggett Group Inc. turned over under seal to Minnesota in March after settling its lawsuit with 20 states suing the tobacco industry. Special Master Gehan was appointed to review the contested papers in a much-watched case brought by Minnesota against the tobacco industry. The Special Master's report recommending the release of the documents is available at:

<http://www.ag.state.mn.us/consumer/tobacco/ SpecialMaster121897.html>.

On 18 December 1997, the commerce committee released the documents. Those documents are available at:

<http://www.house.gov/commerce/TobaccoDocs/ documents.html>.

An alternative link is: <http://143.231.226.4/TobaccoDocs.nsf/>.

The chairman of the Commerce Committee is congressman Thomas Bliley, who is known as the "Congressman from Philip Morris". His district encompasses the Philip Morris plant in Richmond Virginia.

Theories abound as to why a congressman so historically aligned with the tobacco industry would consent to an action seemingly detrimental to the industry he has so zealously protected throughout his career. Was it a public relations ploy to simply release documents that were to be made public anyway? Was it a necessary ploy to release the documents before any actions by the Congress to grant the industry immunity, thus avoiding the spectrum of possible embarrassment should the documents be released after such action? Was Bliley simply reacting to the snub he received from being excluded from the "global settlement" negotiations? Or as John Banzhaf suggests, Bliley possibly conspired with Philip Morris to orchestrate the release of the documents long before serious consideration of federal tobacco legislation begins, and in a form (see below) that makes it difficult for the media and others to appraise them.

Minnesota Attorney General Hubert Humphrey III claims the documents are "only the tip of the iceberg". He testified before the House Commerce Committee on 5 December 1997 encouraging the release of the Liggett documents. His statement is available at: <http://www.ag.state.mn.us/consumer/news/ news. qry? function $=$ fullstory $\mathcal{E}$ L ayout_O uid $1=30>$.

The documents have been scanned and created using Adobe Acrobat. To view these documents, you will need the Adobe PDF 3.0 Viewer or later version. Older versions will not read them. The Adobe Viewer/Reader version 3.0 is available at no charge at:

<http://www.adobe.com/prodindex/acrobat/ readstep. html>.

Thirteen days later, on 30 December 1997, Judge Fitzpatrick ordered the first sanctions ever issued against a American tobacco company. In a particularly scathing ruling the court further ordered the release of 1114 more tobacco industry documents. That order is available at:

$<$ http://www. courts.state.mn.us/districts/second/ tobacco/orders/1914.min.html>.

As Ed Sweda has suggested, criminal defence lawyers should note the response of the tobacco industry - "We must . . not be obsessed by events past".

$$
\star \star \star \star
$$

Physicians for a Smoke-Free Canada <http://www.smoke-free.calenglish/index. htm> Physicians for a Smoke-Free Canada is a national health organisation, founded in 1985 as a registered charity. The organisation consists of Canadian physicians who share one goal: the reduction of tobacco-caused illness through reduced smoking and reduced exposure to secondhand smoke. 
Subjects covered on its web site include: advertising through the years, a newsletter, news briefs, press releases, opinions, humour plus facts about secondhand smoke, and children's health.

A particularly ingenious section is entitled “Take your butt outside!". Created by Ogilvy and Mather, this site is dubbed "The hacker's guide to smoking and the great outdoors". Featuring subtitles such as: "Responsible smokers leave their families", "How to impress squirrels", and "Taking the dog for a drag", numerous rationales are presented to entice smokers to step outside their homes before lighting up, thus protecting the health of the children.

Tobacco use in British Columbia, 1997

$<$ http://www.health.gov.bc.caltobacrs/ index.html>

Recognising that the present rates of tobacco use in British Columbia (Canada) will continue to stretch the resources of the healthcare system beyond sustainability, the Ministry of Health and the Ministry Responsible for

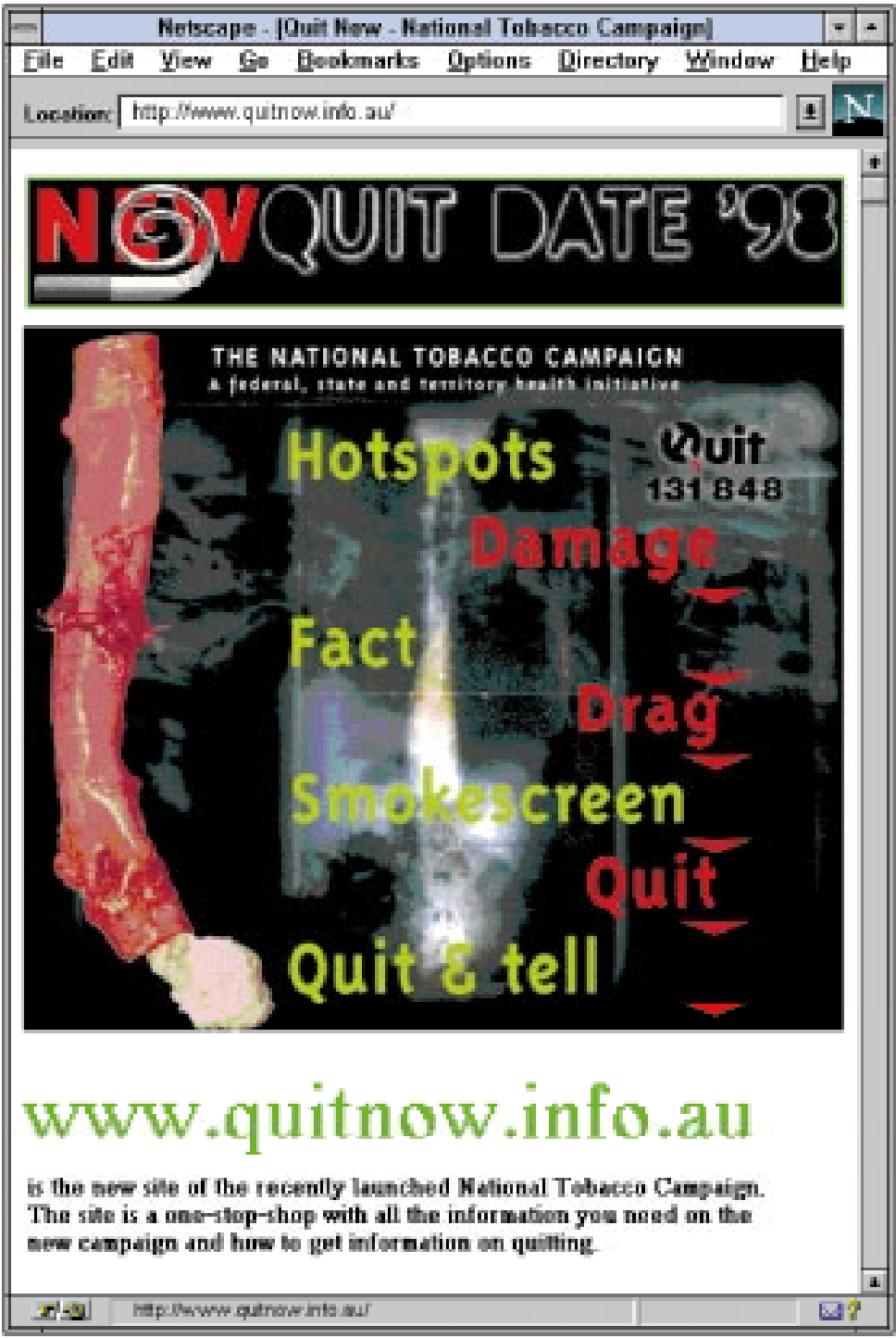

Figure 1 Australian National Tobacco Campaign.
Seniors initiated this province-wide survey on the prevalence of tobacco use.

To stem the recruitment of new smokers among the young and to help more smokers quit, the Ministry contracted the Health and Stroke Foundation of British Columbia and Yukon to manage the project, including establishing an expert committee, chaired by $\mathrm{Dr}$ Ken Prkachin, to review bids, questionnaires, and survey findings.

The survey results are intended to inform the development of public policy and allow the 18 regional health boards and community health services societies, and voluntary health agencies, to plan strategically for the needs of their own communities.

$$
\star \star \star
$$

\section{Australian National Tobacco Campaign} $<$ http://www.quitnow.info.au/>

The web site for the Australian National Tobacco Campaign features the background behind the campaign, the science behind the ads, and stills of the ads as well as other video and audio material (figure 1).

"Hotspots" features news on the campaign's latest developments and the media release archive.

"Damage" features the science behind the campaign advertisements and details the recent research that shows the genetic link between smoking (which damages the p53 gene) and lung cancer.

"FACT" (Facts About the Campaign and Tobacco) gives you the who's who of the campaign, a quit-smoking contact listing for each state and territory, the rationale behind the campaign, and " 10 facts about smoking".

"Drag" allows one to download audio files of the campaign's radio advertisements.

"Smokescreen" allows viewing of images from the campaign's powerful television commercials.

"Quit" features an order form for the Quit Book, while "Quit \& Tell” lets one tell one's own quitting story.

See the cover and cover essay (pages $5-8$ ) in this issue of Tobacco Control for more information on the campaign.

\section{Quit Victoria}

$<h t t p: / / w w w . q u i t . o r g . a u />$

Most of the resources that Quit Victoria publishes and regularly mails to members of the public are available on this well-organised and comprehensive site.

From passive smoking to mental illness and cessation, from social costs of tobacco use to international smoking rates in the young, and from ingredients to herbal cigarettes, almost any subject related to smoking is available on this site.

The Victorian Smoking and Health Program is a joint initiative of the Anti-Cancer Council of Victoria, the Department of Health and Community Services, and the National Heart Foundation, supported substantially with funds from the Victorian Health Promotion Foundation. 
Critique of the British government's request for Formula One tobacco advertising exemption

$<h t t p: / / w w w$. ash.org.uk/press/cttebrf2.html>

Clive Bates, director of Action on Smoking and Health (ASH UK), has posted a critique of the British government's case for an exemption of Formula One racing from the European Union's (EU's) directive to ban tobacco advertising.

The critique is in the form of evidence to a parliamentary committee in response to a letter from Tessa Jowell (the Minister for Public Health) to the EU's presidency announcing Britain's intention to seek an exemption to exclude Formula One from the scope of the EU directive.

\section{Dining in Poland}

$<$ http://www.man.torun.pl/Health/SmokeFree/> As the "center of the smoking universe" moves south from the native land of Copernicus to that of Socrates and Plato, smoking is becoming unfashionable in Poland. So much so that Scott Thompson has produced a smoke-free dining guide for the city of Torun, a beautiful and historic town in the heart of one of the world's leading cigarette-smoking nations.

Scott's guide was produced with the support of the Torun city council, which elected in 1995 to join the World Health Organisation's Tobacco-Free Healthy Cities programme.

The guide not only covers restaurants but also cafés, pizzerias, fast food establishments, and attractions such as churches, a museum, and a planetarium. There is even one bar and one hotel touting smoke-free areas.

Follow ups:

\section{Health Effects of Exposure to Environmental Tobacco Smoke Final Report: September 1997 \\ <http://www.calepa.cahwnet.gov/oehha/docs/ finalets.htm>}

Web Watch reported last year (Tobacco Control 1997;6:147-9) that the California Environmental Protection Agency (Cal-EPA) had released for public comment the most comprehensive review of environmental tobacco smoke (ETS) since the 1986 Surgeon General's Report.

The final report has now been released by the Cal-EPA Office of Environmental Health Hazard Assessment. This overall assessment of ETS includes chapters on respiratory health effects, reproductive and developmental effects, cardiovascular effects, cancer, and exposure measurement and prevalence. The preface and executive summary were reproduced in Tobacco Control (1997;6:34653).

\section{Broin settlement and challenge}

The same Web Watch reported on the Broin/Young flight attendants' class action lawsuit against the tobacco industry. The suit has resulted in an historic settlement that allows individual plaintiff suits to continue against the tobacco industry - even those whose statute of limitations has expired.

The text of the Broin settlement is available at:

<http://www.tobacco.neu.edu/extra/hotdocs/ broin.htm $>$.

A legal challenge was mounted to this settlement by Eric G Olsen, an attorney from Jensen Beach, Florida. However, in a stinging rebuke issued by Judge Robert P Kaye on 5 February 1998, the court granted Final Approval of the proposed Settlement in its entirety, and directed all parties to implement and comply with the settlement agreement.

Judge Kaye's order can be viewed at: $<$ http://www.gate.net/ jcannon/980205k1.txt>.

See the quotation and cartoon related to the Broin case on page 78 in this issue of Tobacco Control.

\section{Boyse memo}

An article by Simon Chapman ("Vast sums of money . . . to keep the controversy alive - the 1988 BAT memo") in Tobacco Control (1997;6:236-9) described a memo by BAT's Sharon Boyse reporting on a meeting on environmental tobacco smoke (ETS) hosted by Philip Morris. At the meeting, according to the memo, it was announced that the Washington, DC, law firm of Covington and Burling would set up a London office to spend vast sums of money to coordinate activities to review scientific literature or carry out work on ETS to keep the controversy alive.

The text of the Boyse memo is available at: $<$ http://www.gate.net/ jcannon/documents/ 880217b1.txt>.

\section{Advertising spoofs}

Tobacco Control (1996;5:109) published as a "filler" a spoof on Kool cigarette advertising. Instead of a hip, sexy, fun-loving "Totally Kool" smoker not yet diagnosed with hideous tumours, the advertisement shows a young "Utter Fool" smoker during the tumour germination/cultivation growth cycle.

The "Utter Fool" advertisement was created by Adbusters and is available at <http://www.adbusters.org/Gallery/fool.html>.

The Adbusters site was created by The Media Foundation, a Canadian media activist organisation, which publishes Adbusters magazine and runs the Powershift Advocacy Agency, a group of social marketers and media activists.

Hardly content with the "Utter Fool" spoof, Adbusters has produced "Joe Chemo" spoofs depicting Joe Camel in his retirement years (figure 2). Joe's retirement activities can be viewed at:

$<$ <ttp://www.adbusters.org/Gallery/joe1.html> <http://www.adbusters.org/Gallery/joe2.html>. 


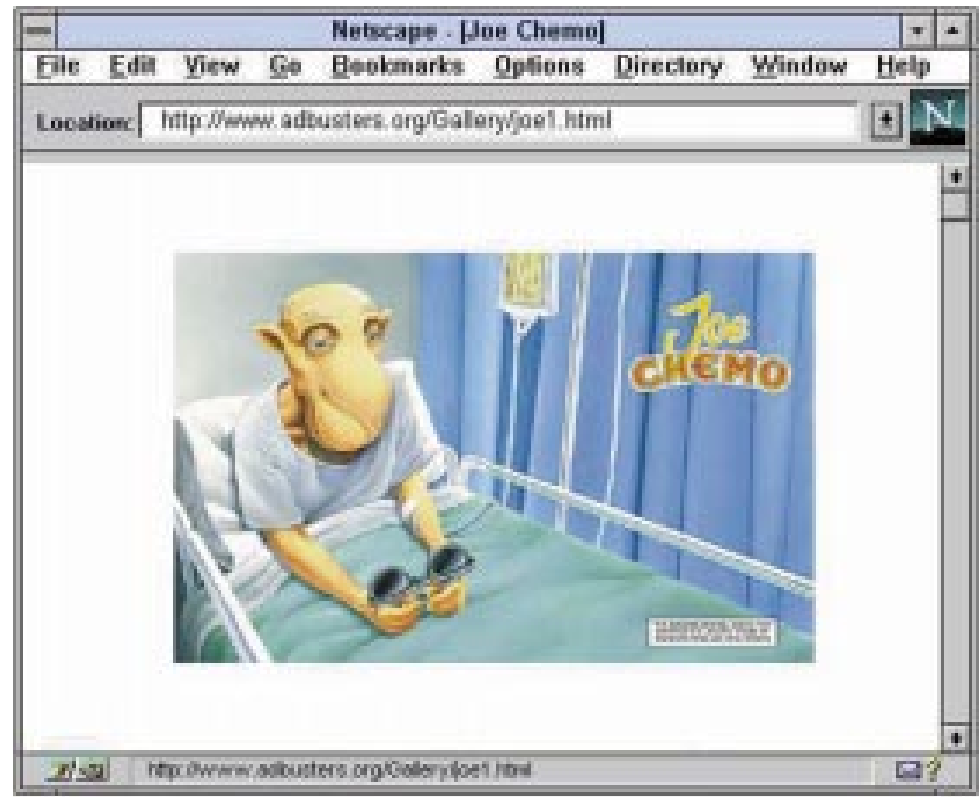

Figure 2 foe Camel enjoying his retirement.

Want to see "Joe Chemo" share space with Marlboro and Merit on the pages of Harper's magazine? Initially quoting a non-profit society rate to Adbusters, Harper's retracted the offer after viewing the parodies, claiming that such material would be unfair to Marlboro. To learn about Adbusters' campaign to raise the money necessary to run the "Joe Chemo" spoof at full commercial rates, go to:

<http://www. adbusters.org/Subs/chemo.html>.

Profits from the sale of "Joe Chemo" postcards, posters, and teeshirts go directly to the Harper's fund. The largest single contribution to date was from the Washington State Department of Health for 10000 posters.

Brewing away behind the scenes in Washington State is a long-range legal strategy to revoke Philip Morris' corporate charter. To learn more about this ingenious initiative, point your browser to:

$<$ http://www.adbusters.org/Corporate/

charter.html>.

Always eager to promote a good idea, Mother fones has devoted a page to Adbusters' "Utter Fool" spoof:

<http://www.motherjones.com/hellraiser_central/ sideshow/utterfool.html $>$.

Another Adbuster spoof promoted by Mother fones is "The New Smoking Section"-an outside area near exit doors claimed by huddled masses of smokers shivering against the cold during workday breaks and, in California, during happy hour: <http://www.motherjones.com/hellraiser_centrall sideshow/marlboro.html>.

Perhaps a new health warning for cigarette packs: "SMOKING CAUSES HYPOTHERMIA AS WELL AS PREMATURE DEATH"?

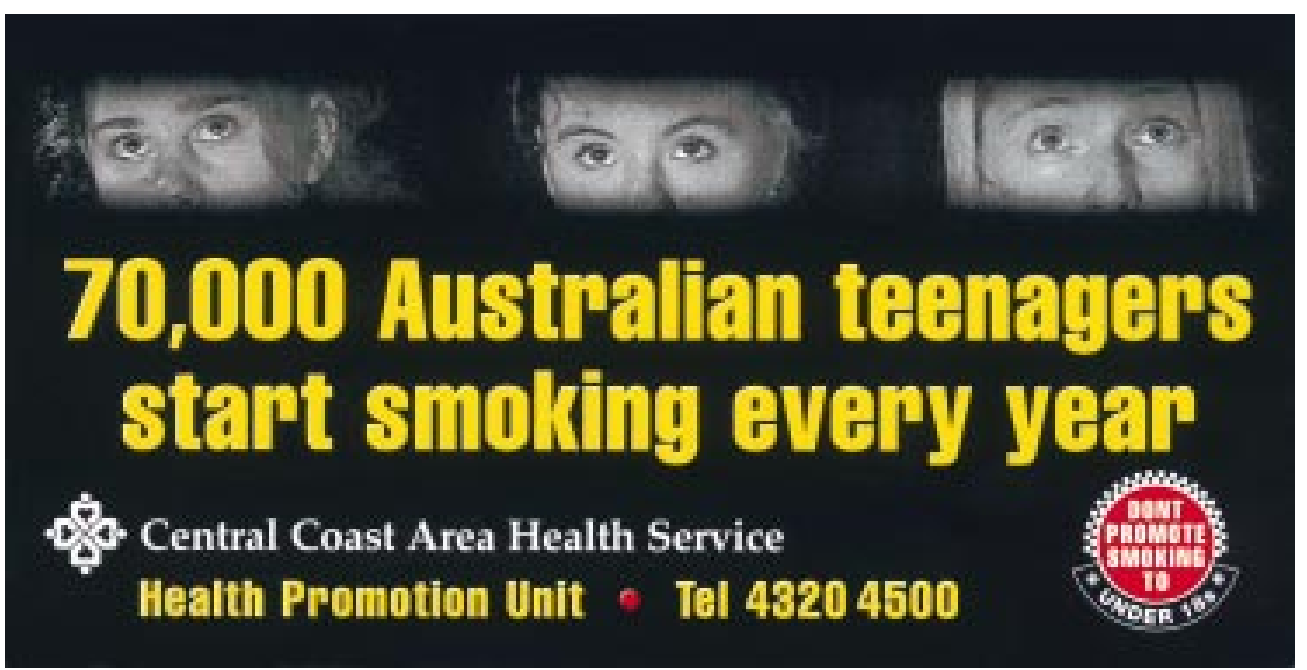

Smokes in the movies: raising awareness The Health Promotion Unit of the Central Coast Health Service in New South Wales, Australia, has been running pre-movie slide ads to raise awareness in teenagers and adults about the influence of smoking in movies. The voice-over is by Peter Sterling, a former high-profile Australian rugby league player. The script for the above ad (for adults) says: "Hi, this is Peter Sterling, with a word on smoking. ... Movies and actors can make smoking look normal and desirable. Seventy thousand Australian kids start smoking every year. ... Smoking still is not part of the Australian Film Classification Guidelines. Keep your eyes wide open." 